\title{
Chemical preparation, thermal behavior and infrared studies of the new cyclotriphosphate tetrahydrate of manganese and distrontium, $\mathrm{MnSr}_{2}\left(\mathrm{P}_{3} \mathrm{O}_{9}\right)_{2.4} \mathbf{4 H}_{2} \mathrm{O}$
}

\author{
Smail El Makhloufy 1,*, Malika Tridane ${ }^{1,2}$, El Mehdi Majdi ${ }^{1}$, Hamza Marouani ${ }^{1}$, Soufiane Zerraf ${ }^{, 1}$, \\ Mustafa Belhabra ${ }^{1}$, Abdelouahed Cherqaoui ${ }^{1}$ and Said Belaaouad ${ }^{1}$ \\ ${ }^{1}$ Laboratory of Chemistry-Physics of Materials, Faculty of Sciences Ben M'Sik B. P. 7955, Hassan II University \\ of Casablanca, Casablanca, Morocco \\ ${ }^{2}$ Regional Center for Education and Training Occupations Casablanca Anfa, Bd Bir Anzarane Casablanca, \\ Morocco
}

\begin{abstract}
A new cyclotriphosphate tetrahydrate of manganese and distrontium, $\mathrm{MnSr}_{2}\left(\mathrm{P}_{3} \mathrm{O}_{9}\right)_{2} .4 \mathrm{H}_{2} \mathrm{O}$, was obtained as a polycrystalline sample by the method of ion-exchange resin. The cyclotriphosphate studied in this work is the second one having the formula $\mathrm{MnSr}_{2}\left(\mathrm{P}_{3} \mathrm{O}_{9}\right)_{2} \cdot 4 \mathrm{H}_{2} \mathrm{O}$ after $\mathrm{BaZn}_{2}\left(\mathrm{P}_{3} \mathrm{O}_{9}\right) 2.10 \mathrm{H}_{2} \mathrm{O}$. Its crystallographic characterization, infrared studies and thermal behavior are given. The studied phosphate crystallizes in the triclinic system, P-1, with the following unit cell parameters : $a=6,653(1) \AA, b=7,110(1) \AA, c=5,123(1) \AA$, $\alpha=103,37(2)^{\circ}, \beta=95,81(2)^{\circ}, \gamma=93,04(2)^{\circ}$ and $\mathrm{Z}=1$. The intermediate products of dehydration of $\mathrm{MnSr}_{2}\left(\mathrm{P}_{3} \mathrm{O}_{9}\right)_{2} .4 \mathrm{H}_{2} \mathrm{O}$ are $\mathrm{MnSr}_{2}\left(\mathrm{P}_{3} \mathrm{O}_{9}\right)_{2} .2 \mathrm{H}_{2} \mathrm{O}$, mixture of $\left(\left[\mathrm{Mn}\left(\mathrm{PO}_{3}\right)_{2}\right]_{\infty}+2 \gamma\left[\mathrm{Sr}\left(\mathrm{PO}_{3}\right)_{2}\right]_{\infty}\right)$ and mixture of $\left(\left[\mathrm{Mn}\left(\mathrm{PO}_{3}\right)_{2}\right]_{\infty}+2 \beta\left[\mathrm{Sr}\left(\mathrm{PO}_{3}\right)_{2}\right]_{\infty}\right)$. The thermal behavior of the studied condensed phosphate has been investigated and interpreted by IR absorption and X-ray diffraction experiments. The title compound can be used as catalyst, ion exchanger, the reactant in ionic conditions, intercalation reactions, superphosphate fertilizer and as an inorganic pigment in ceramics.
\end{abstract}

Keywords: Cyclotriphosphate; thermal behavior; vibration study; thermogravimetric analysis.

\section{Introduction}

Multivalent metal phosphates have some technologically useful properties ${ }^{1}$. However, this has posed the question of industrial manufacture of several condensed phosphates, which is required in the form of single crystals or polycrystalline samples. Till now, there are only four cyclotriphosphates with the general formula $\mathrm{M}^{\mathrm{II}} \mathrm{M}_{2}^{\prime}{ }_{2} \mathrm{II}\left(\mathrm{P}_{3} \mathrm{O}_{9}\right) \cdot \mathrm{nH}_{2} \mathrm{O}$. These phosphates are $\mathrm{Ba}_{2} \mathrm{Zn}\left(\mathrm{P}_{3} \mathrm{O}_{9}\right) \cdot 10 \mathrm{H}_{2} \mathrm{O}{ }^{2}$, $\mathrm{MnCa}_{2}\left(\mathrm{P}_{3} \mathrm{O}_{9}\right) \cdot 10 \mathrm{H}_{2} \mathrm{O}, \quad \mathrm{MnSr}_{2}\left(\mathrm{P}_{3} \mathrm{O}_{9}\right) \cdot 4 \mathrm{H}_{2} \mathrm{O}$ and $\mathrm{MnBa}_{2}\left(\mathrm{P}_{3} \mathrm{O}_{9}\right) \cdot 6 \mathrm{H}_{2} \mathrm{O}{ }^{3,4}$. The crystalline structure was solved only for $\mathrm{Ba}_{2} \mathrm{Zn}\left(\mathrm{P}_{3} \mathrm{O}_{9}\right) \cdot 10 \mathrm{H}_{2} \mathrm{O}$. During a systematic investigation of this series of cyclotriphosphates in our laboratory, we obtained $\mathrm{MnSr}_{2}\left(\mathrm{P}_{3} \mathrm{O}_{9}\right) \cdot 4 \mathrm{H}_{2} \mathrm{O}$ whose structure is unknown till now. The present work describes the chemical preparation, crystallographic characterization, vibrational study and thermal behavior of a new cyclotriphosphate, $\mathrm{MnSr}_{2}\left(\mathrm{P}_{3} \mathrm{O}_{9}\right)_{2} .4 \mathrm{H}_{2} \mathrm{O}$, by X-ray diffraction, infrared spectrometry, thermal analyses TGA, DTA and DSC.

\section{Results and Discussion}

\subsection{Chemical preparation}

Through a column of ion exchange resin $\left(\mathrm{Na}^{+}\right.$by $\left.\mathrm{H}^{+}\right)$, "Amberlite IR 120" 5 . A concentrated solution of $\mathrm{Na}_{3} \mathrm{P}_{3} \mathrm{O}_{9}$ is slowly added. The cyclotriphosphoric acid $\mathrm{H}_{3} \mathrm{P}_{3} \mathrm{O}_{9}$ thus obtained is immediately neutralized with a mixture of stoichiometric amounts of carbonates, $\mathrm{MnCO}_{3}$ and $\mathrm{SrCO} 3$, according to the following chemical reaction:

$$
2 \mathrm{H}_{3} \mathrm{P}_{3} \mathrm{O}_{9}+2 \mathrm{SrCO}_{3}+\mathrm{MnCO}_{3}+\mathrm{H}_{2} \mathrm{O} \longrightarrow \mathrm{MnSr}_{2}\left(\mathrm{P}_{3} \mathrm{O}_{9}\right)_{2} .4 \mathrm{H}_{2} \mathrm{O}+3 \mathrm{CO}_{2}
$$

The solution abandoned for a few days, $\mathrm{MnSr}_{2}\left(\mathrm{P}_{3} \mathrm{O}_{9}\right)_{2} .4 \mathrm{H}_{2} \mathrm{O}$ is obtained in the form of crystals and powder having a pinkish white color. $\mathrm{Na}_{3} \mathrm{P}_{3} \mathrm{O}_{9}$ was obtained by thermal treatment of sodium dihydrogenomonophosphate $\mathrm{NaH}_{2} \mathrm{PO}_{4}$, at $530^{\circ} \mathrm{C}$ for 5

*Corresponding author: Smail El Makhloufy

E mail:s smail.elmakhloufy@gmail.com

DOI: http://dx.doi.org/10.13171/mjc941911141082sem hours in the air, according to the following chemical reaction:

$3 \mathrm{NaH}_{2} \mathrm{PO}_{4} \longrightarrow \mathrm{Na}_{3} \mathrm{P}_{3} \mathrm{O}_{9}+3 \mathrm{H}_{2} \mathrm{O}$

Received September 23, 2019

Accepted October 17, 2019

Published November 14, 2019 


\subsection{Chemical analyses and dehydration}

The results of the chemical analyses, by atomic absorption and dehydration by heating up to $600^{\circ} \mathrm{C}$ the title compound, are in total accordance with the formula $\mathrm{MnSr}_{2}\left(\mathrm{P}_{3} \mathrm{O}_{9}\right)_{2} .4 \mathrm{H}_{2} \mathrm{O}$ and are gathered in Table 1, with a standard deviation of 0.001 .

Table 1. Results of the chemical analyses and dehydration of $\mathrm{MnSr}_{2}\left(\mathrm{P}_{3} \mathrm{O}_{9}\right)_{2} .4 \mathrm{H}_{2} \mathrm{O}$

\begin{tabular}{|c|c|c|c|c|}
\hline & $\mathbf{P}$ & $\mathbf{S r}$ & $\mathbf{M n}$ & $\mathbf{H}_{2} \mathbf{O}$ \\
\hline Theoretical & 6 & 2 & 1 & 4 \\
\hline Experimental & 5.902 & 1,971 & 1.002 & 3.991 \\
\hline
\end{tabular}

\subsection{Stability}

The cyclotriphosphate tetrahydrate of manganese and distrontium, $\mathrm{MnSr}_{2}\left(\mathrm{P}_{3} \mathrm{O}_{9}\right)_{2} .4 \mathrm{H} 2 \mathrm{O}$, is stable in the conditions of temperature and pressure of our laboratory until $60^{\circ} \mathrm{C}$. We have followed, by IR spectrometry, X-ray diffraction and thermogravimetric analyses, the stability of $\mathrm{MnSr}_{2}\left(\mathrm{P}_{3} \mathrm{O}_{9}\right)_{2} .4 \mathrm{H} 2 \mathrm{O}$ during 11 months, and no evolution were observed.

\subsection{Crystallographic characterization}

The crystal of $\mathrm{MnSr}_{2}\left(\mathrm{P}_{3} \mathrm{O}_{9}\right)_{2} \cdot 4 \mathrm{H}_{2} \mathrm{O}$ has no isotypic compound. An automatic indexation using the Dicvol program ${ }^{6}$, showed that compound crystallizes in the triclinic system with $\mathrm{M}(20)=29.6$ and $\mathrm{F}(30)=34.4$ and its space group is $\mathrm{P}-1$. The unit-cell parameters calculated and refined by the least-squares method are as follows:

$\mathrm{a}=6,653(1) \AA, \mathrm{b}=7,110(1) \AA, \mathrm{c}=5,123(1) \AA, \alpha=$ $103,37(2)^{\circ}, \beta=95,81(2)^{\circ}, \gamma=93,04(2)^{\circ}$ and $\mathrm{Z}=$ 1.The X-ray diffractogram of $\mathrm{MnSr}_{2}\left(\mathrm{P}_{3} \mathrm{O}_{9}\right)_{2} .4 \mathrm{H}_{2} \mathrm{O}$ is reported in Figure 1 and Table 2.

Table 2. X-ray powder diffraction data of $\mathrm{MnSr}_{2}\left(\mathrm{P}_{3} \mathrm{O}_{9}\right)_{2} .4 \mathrm{H}_{2} \mathrm{O}$.

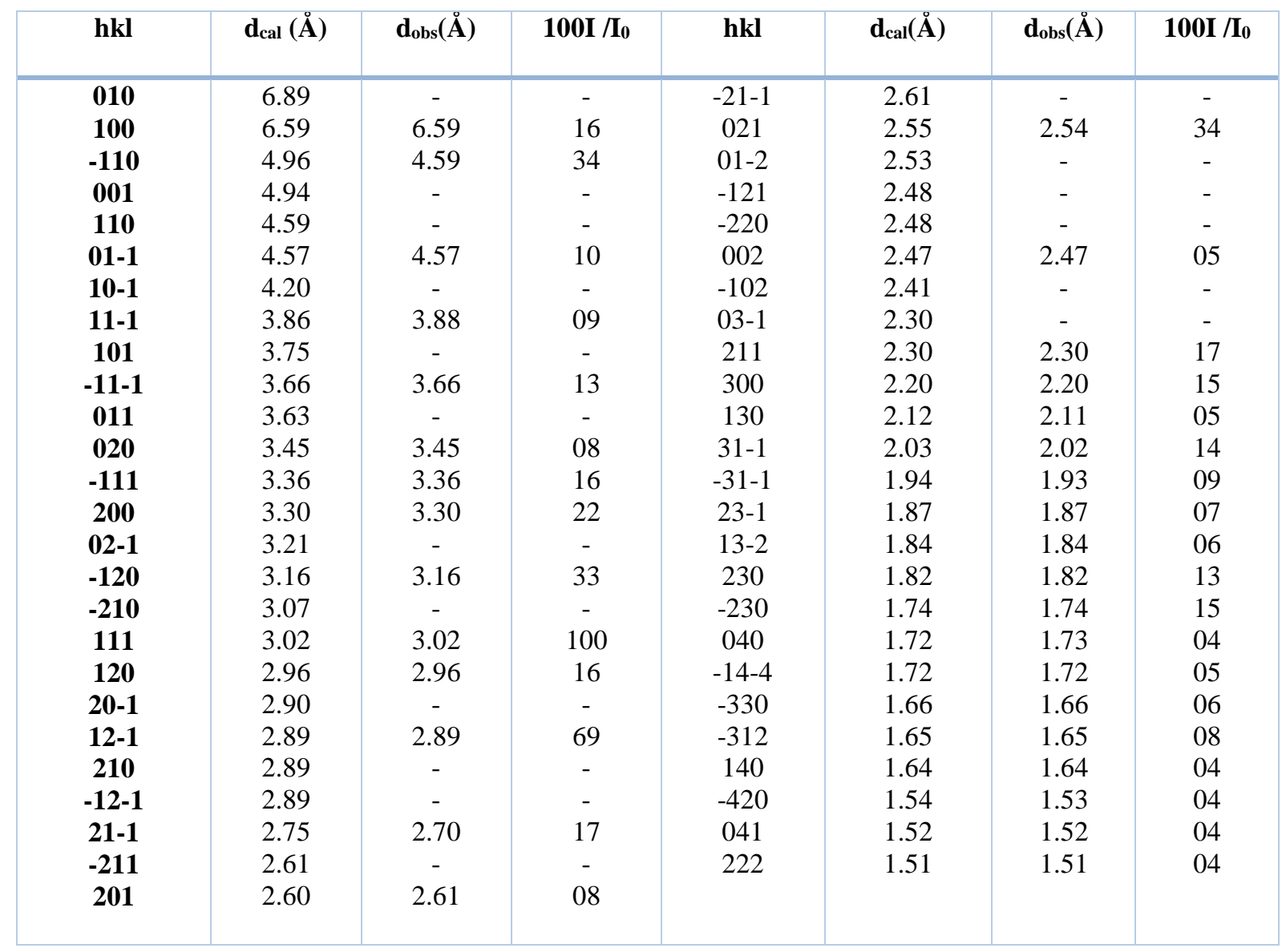




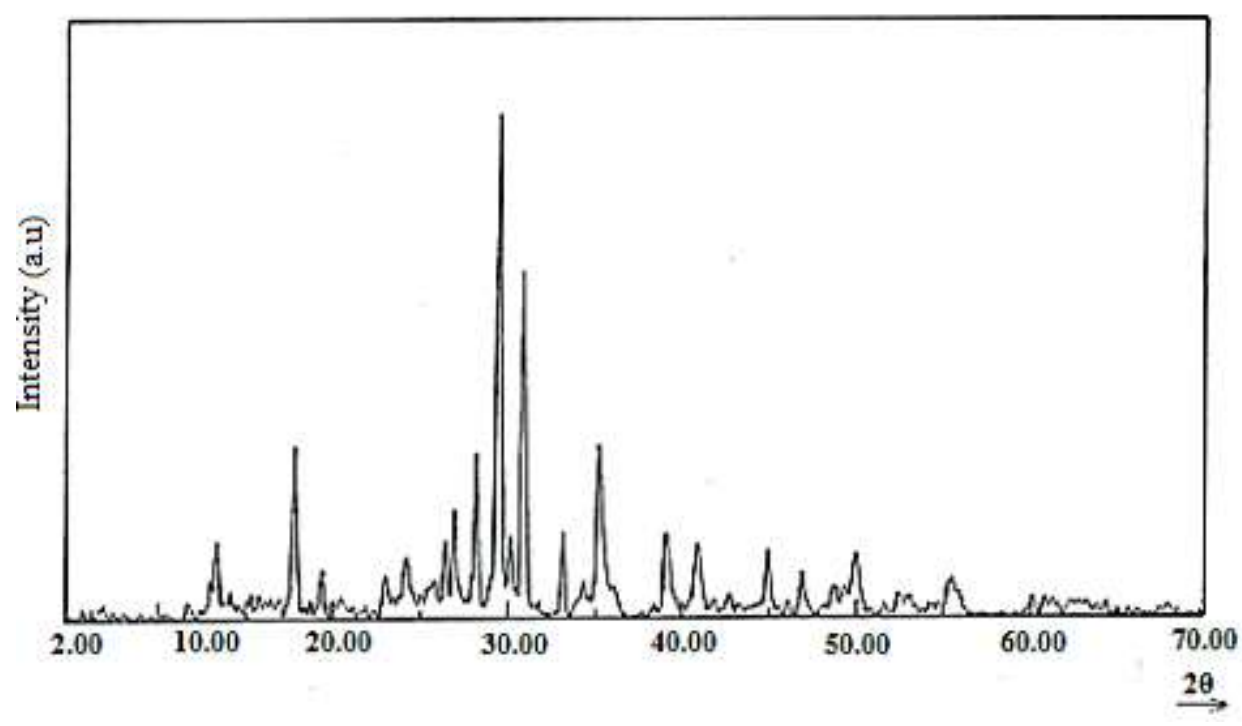

Figure 1. X-ray powder diffractogram of $\mathrm{MnSr}_{2}\left(\mathrm{P}_{3} \mathrm{O}_{9}\right)_{2} \cdot 4 \mathrm{H}_{2} \mathrm{O}$

possibly the water-cycle interaction and the rotation of the water molecules, six intense bands, of which four of strong intensity are observed at $1100 \mathrm{~cm}^{-1}$, $765 \mathrm{~cm}^{-1}$, two of them appear at $\left(1297,1255 \mathrm{~cm}^{-1}\right)$ and $\left(1002,975 \mathrm{~cm}^{-1}\right)$, two others of high intensity at 1110 and $765 \mathrm{~cm}^{-1}$. The other two bands are relatively thinner and of average intensity, at 1155 and $691 \mathrm{~cm}^{-}$ ${ }^{1}$. In addition to these bands, the IR spectrum has two bands of very low intensity at 831 and $813 \mathrm{~cm}^{-1} 7,8$.

- Between 640 and $400 \mathrm{~cm}^{-1}$, a domain characterizing the deformation vibrations of oxygens outside the $\mathrm{P}_{3} \mathrm{O}_{9}{ }^{3-}$ cycle $\left(\delta \mathrm{OPO}^{-}+\delta \mathrm{POP}\right)$, at a frequency of 620 $\mathrm{cm}^{-1}, 610 \mathrm{~cm}^{-1}, 523 \mathrm{~cm}^{-1}, 500 \mathrm{~cm}^{-1}$ and $450 \mathrm{~cm}^{-1}$, the band at $523 \mathrm{~cm}^{-1}$ is intense ${ }^{9,10}$.

\subsection{IR Studies}

2.5.1. Characterization of $\mathrm{MnSr}_{2}\left(\mathrm{P}_{3} \mathrm{O}_{9}\right)_{2} .4 \mathrm{H}_{2} \mathrm{O}$ by IR vibration spectrometry

The IR absorption spectrum of $\mathrm{MnSr}_{2}\left(\mathrm{P}_{3} \mathrm{O}_{9}\right)_{2} .4 \mathrm{H}_{2} \mathrm{O}$ is reported in Figure 2 and contains:

-In the spectral region $4000-3000 \mathrm{~cm}^{-1}$, characteristic of the $\mathrm{OH}$ valence bands, single broadband at 3450 $\mathrm{cm}^{-1}$;

-In the range, $1700-1600 \mathrm{~cm}^{-1}$, characteristic of the water deformation bands, two bands of very high intensity located respectively at $1640 \mathrm{~cm}^{-1}$ and 1606 $\mathrm{cm}^{-1}$.

- Between 1400 and $640 \mathrm{~cm}^{-1}$, the characteristic domain of the valence bands of the $\mathrm{P}_{3} \mathrm{O}_{9}{ }^{3-}$ ring,

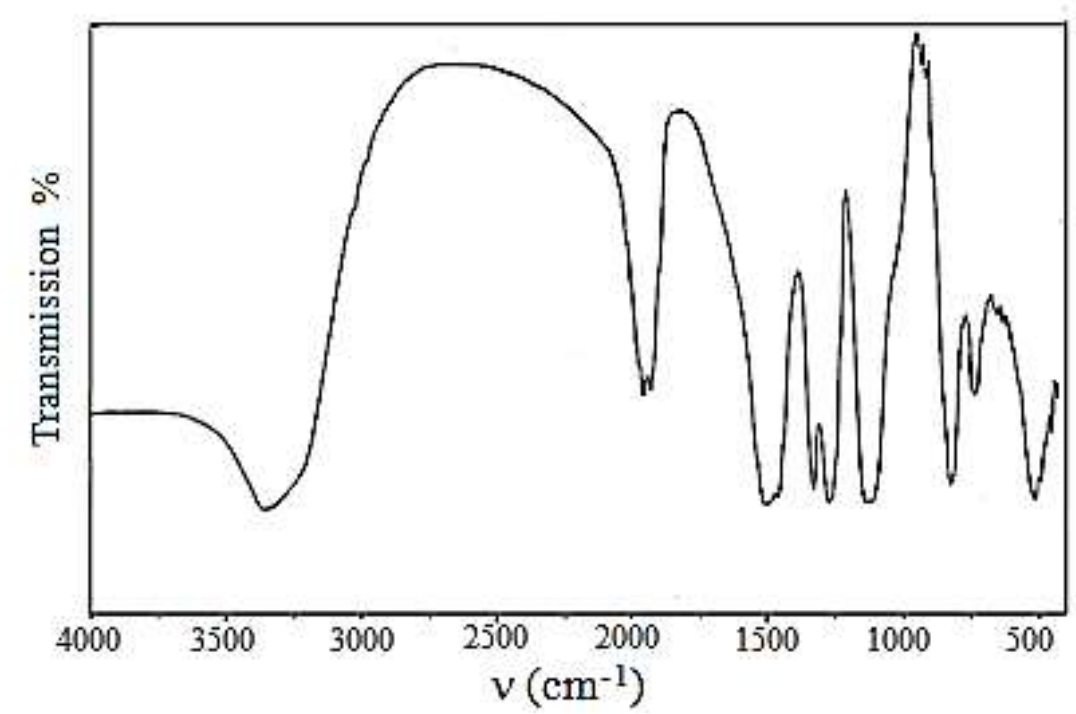

Figure 2. IR spectra of the phosphate $\mathrm{MnSr}_{2}\left(\mathrm{P}_{3} \mathrm{O}_{9}\right)_{2} \cdot 4 \mathrm{H}_{2} \mathrm{O}$ 
Table 3. Attribution of the IR frequencies of the $\mathrm{P}_{3} \mathrm{O}_{9}{ }^{3-}$ cycle with approximate symmetry $\mathrm{C}_{3 \mathrm{v}}$ in $\mathrm{MnSr}_{2}\left(\mathrm{P}_{3} \mathrm{O}_{9}\right)_{2} .4 \mathrm{H}_{2} \mathrm{O}$.

\begin{tabular}{|l|l|}
\hline $\boldsymbol{v}\left(\mathbf{c m}^{-\mathbf{1}}\right)$ & Vibration \\
\hline $\mathbf{3 4 5 0}$ & $v_{\mathrm{OH}}$ \\
$\mathbf{1 6 4 0}$ & \\
$\mathbf{1 6 0 6}$ & $\delta \mathrm{HOH}^{-129}$ \\
\hline $\mathbf{1 2 9 7}$ & $v_{\text {as }} \mathrm{OPO}^{-}$ \\
\hline $\mathbf{1 1 5 5}$ & \\
$\mathbf{1 1 1 0}$ & $v_{\mathrm{s}} \mathrm{OPO}^{-}$ \\
\hline $\mathbf{1 0 0 2}$ & \\
$\mathbf{9 7 5}$ & \\
$\mathbf{8 3 1}$ & $v_{\text {as }} \mathrm{POP}^{-}$ \\
$\mathbf{8 1 3}$ & \\
\hline $\mathbf{7 6 5}$ & $v_{\mathrm{s}} \mathrm{POP}^{-}$ \\
$\mathbf{6 9 1}$ & \\
\hline $\mathbf{6 2 0}$ & $\delta \mathrm{OPO}^{-}$ \\
$\mathbf{6 1 0}$ & + \\
$\mathbf{5 2 3}$ & $\delta \mathrm{POP}^{-}$ \\
\hline $\mathbf{5 0 0}$ & \\
\hline $\mathbf{4 5 0}$ & \\
\hline
\end{tabular}

$$
\mathrm{MnSr}_{2}\left(\mathrm{P}_{3} \mathrm{O}_{9}\right)_{2} .4 \mathrm{H}_{2} \mathrm{O}
$$

$100^{\circ} \mathrm{C}$

The departure of the two water molecules of cyclotriphosphate $\mathrm{MnSr}_{2}\left(\mathrm{P}_{3} \mathrm{O}_{9}\right) \quad{ }_{2} .2 \mathrm{H}_{2} \mathrm{O}$ between $150^{\circ} \mathrm{C}$ and $200^{\circ} \mathrm{C}$. is responsible for the structural disorganization of the latter and consequently for obtaining a product of low crystallinity (Figure 3c). At $250^{\circ} \mathrm{C}$, a product is obtained whose X-ray diffractogram contains the characteristic lines of two infinite-chain polyphosphates which are: manganese polyphosphate, $\left[\mathrm{Mn}\left(\mathrm{PO}_{3}\right)_{2}\right]_{\infty}{ }^{12}$ and strontium polyphosphate form $\gamma, \gamma\left[\mathrm{Sr}\left(\mathrm{PO}_{3}\right)_{2}\right]_{\infty}{ }^{13}$ (Figure 3d). So from $250^{\circ} \mathrm{C}$, polyphosphate reorganization took

$$
\mathrm{MnSr}_{2}\left(\mathrm{P}_{3} \mathrm{O}_{9}\right)_{2} \cdot 4 \mathrm{H}_{2} \mathrm{O}(\mathrm{s}) \stackrel{200-400^{\circ} \mathrm{C}}{\longrightarrow}
$$

Beyond $450^{\circ} \mathrm{C}, \gamma\left[\mathrm{Sr}\left(\mathrm{PO}_{3}\right)_{2}\right]_{\infty}$ begins to transform into the second allotropic form $\beta, \beta\left[\operatorname{Sr}\left(\mathrm{PO}_{3}\right)_{2}\right]_{\infty}{ }^{14,15}$. The X-ray pattern of $\mathrm{MnSr}_{2}\left(\mathrm{P}_{3} \mathrm{O}_{9}\right)_{2} .4 \mathrm{H}_{2} \mathrm{O}$ heated to $550^{\circ} \mathrm{C}$ contains all the $\mathrm{X}$-ray diffraction peaks of the two polyphosphates $\left[\mathrm{Mn}\left(\mathrm{PO}_{3}\right)_{2}\right]_{\infty}$ and $\beta\left[\mathrm{Sr}\left(\mathrm{PO}_{3}\right)_{2}\right]_{\infty}$.

\subsubsection{Symmetry of the cycle $\mathrm{P}_{3} \mathrm{O}_{9}{ }^{3-}$ contained in} $\mathrm{MnSr}_{2}\left(\mathrm{P}_{3} \mathrm{O}_{9}\right)_{2.4 \mathrm{H}_{2} \mathrm{O}}$

All the spectral characteristics of a cycle $\mathrm{P}_{3} \mathrm{O}_{9}{ }^{3-}$ deformed, of pseudo-symmetry $\mathrm{C}_{3 \mathrm{~V}}{ }^{11}$, are in the absorption spectrum IR of $\mathrm{MnSr}_{2}\left(\mathrm{P}_{3} \mathrm{O}_{9}\right)_{2} \cdot 4 \mathrm{H}_{2} \mathrm{O}$. Indeed, the IR absorption spectrum of $\mathrm{MnSr}_{2}\left(\mathrm{P}_{3} \mathrm{O}_{9}\right)_{2} .4 \mathrm{H}_{2} \mathrm{O}$ between 1400 and $400 \mathrm{~cm}^{-1}$, contains in addition to the four very intense $\mathrm{P}_{3} \mathrm{O}_{9}{ }^{3-}$ plan bands, which appear at $\left(1297,1255 \mathrm{~cm}^{-1}\right), 1110$ $\mathrm{cm}^{-1},\left(1002,975 \mathrm{~cm}^{-1}\right)$ and $765 \mathrm{~cm}^{-1}$ respectively, we observe the bands that characterize any low symmetry with respect to $C_{3 \mathrm{~h}}$ symmetry. These are the bands observed at $1155 \mathrm{~cm}^{-1}$ and $691 \mathrm{~cm}^{-1}$. The presence of these last two bands and the splitting of the first bands are typical of a cycle with pseudo-symmetry $\mathrm{C}_{3 \mathrm{v}}$.

\subsection{Thermal analysis}

2.6.1. Thermal dehydration of $\mathrm{MnSr}_{2}\left(\mathrm{P}_{3} \mathrm{O}_{9}\right)_{2} .4 \mathrm{H}_{2} \mathrm{O}$ by step manner of temperatures, at atmospheric pressure, by X-ray diffraction

The examination of the $\mathrm{X}$-ray diffraction of $\mathrm{MnSr}_{2}\left(\mathrm{P}_{3} \mathrm{O}_{9}\right)_{2} .4 \mathrm{H}_{2} \mathrm{O}$ heated to $100^{\circ} \mathrm{C}$ (Figure $3 \mathrm{~b}$ ) shows that the product obtained is well crystallized. This would probably be the evolution towards an intermediate cyclotriphosphate $\mathrm{MnSr}_{2}\left(\mathrm{P}_{3} \mathrm{O}_{9}\right)_{2} .2 \mathrm{H}_{2} \mathrm{O}$ according to the following reaction:

$\mathrm{MnSr}_{2}\left(\mathrm{P}_{3} \mathrm{O}_{9}\right)_{2} .2 \mathrm{H}_{2} \mathrm{O}+2 \mathrm{H}_{2} \mathrm{O}$

place. Between 200 and $400{ }^{\circ} \mathrm{C}$, when the temperature increases, the $\mathrm{X}$-ray diffraction lines of the polyphosphate mixture $\left(\left[\mathrm{Mn}\left(\mathrm{PO}_{3}\right)_{2}\right]_{\infty}\right.$ $\left.+2 \gamma\left[\mathrm{Sr}\left(\mathrm{PO}_{3}\right)_{2}\right]_{\infty}\right){ }^{12,13}$, increase in number and in intensity and up to $400{ }^{\circ} \mathrm{C}$ where appear all the X-ray diffraction lines of these two polyphosphates (Figure 3e). The dehydration reaction of $\mathrm{MnSr}_{2}\left(\mathrm{P}_{3} \mathrm{O}_{9}\right)_{2} .4 \mathrm{H}_{2} \mathrm{O}$ from 250 to $400^{\circ} \mathrm{C}$ as follows:

$\left(\left[\mathrm{Mn}\left(\mathrm{PO}_{3}\right)_{2}\right]_{\infty}+2 \gamma\left[\mathrm{Sr}\left(\mathrm{PO}_{3}\right)_{2}\right]_{\infty}\right)+4 \mathrm{H}_{2} \mathrm{O}$

$\left(\left[\mathrm{Mn}\left(\mathrm{PO}_{3}\right)_{2}\right]_{\infty}+2 \beta\left[\mathrm{Sr}\left(\mathrm{PO}_{3}\right)_{2}\right]_{\infty}\right)$ is, therefore, the final product resulting from the calcination of $\mathrm{MnSr}_{2}\left(\mathrm{P}_{3} \mathrm{O}_{9}\right)_{2} \cdot 4 \mathrm{H}_{2} \mathrm{O}$ at $550^{\circ} \mathrm{C}$ under atmospheric pressure (Figure $3 \mathrm{f}$ ). 


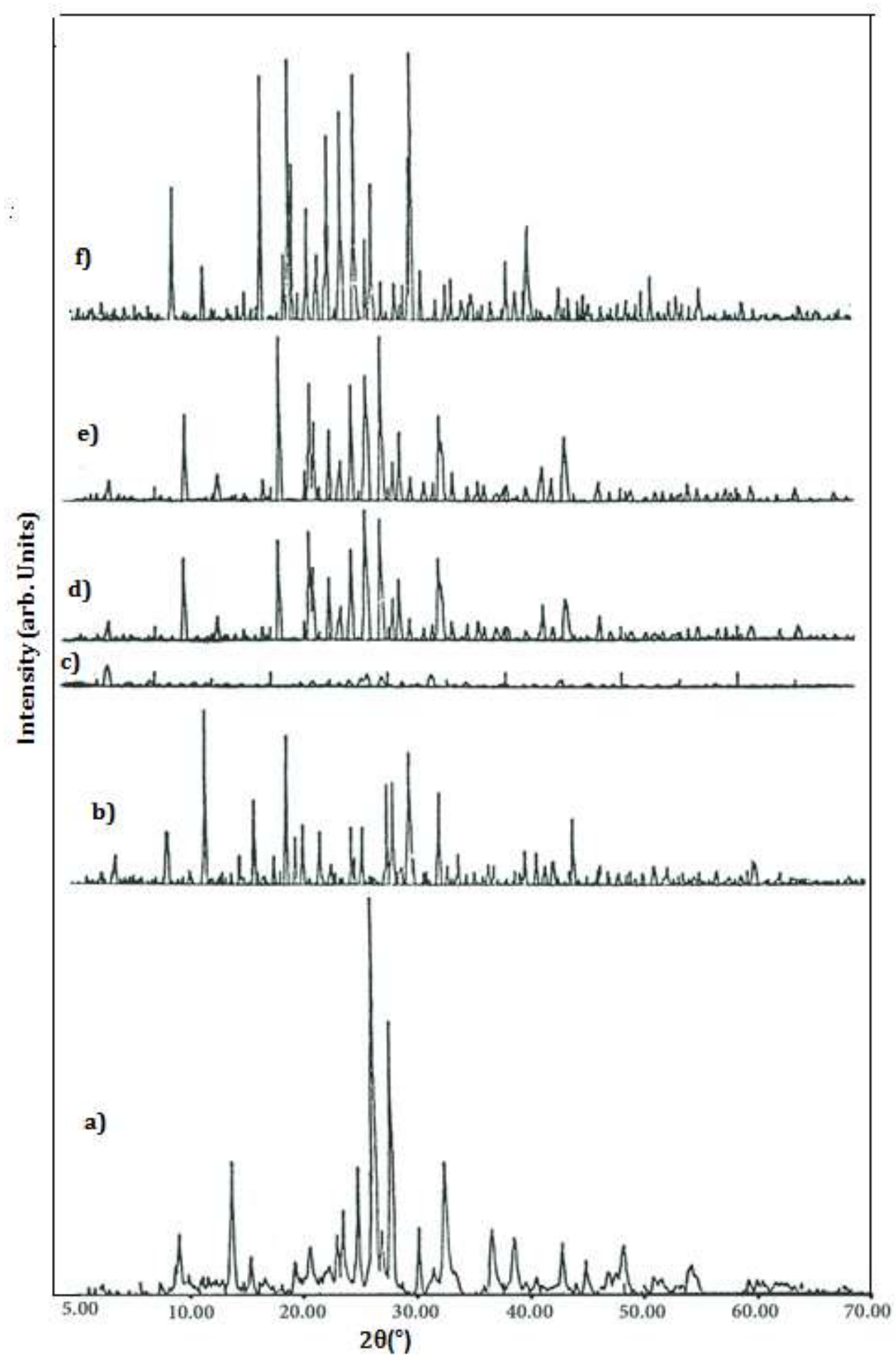

Figure 3. X-ray diffractograms of $\mathrm{MnSr}_{2}\left(\mathrm{P}_{3} \mathrm{O}_{9}\right)_{2} \cdot 4 \mathrm{H}_{2} \mathrm{O}$ (a) and its dehydration products at atmospheric pressure:

(b) $100^{\circ} \mathrm{C}, 200^{\circ} \mathrm{C}(\mathrm{d})$ evolution to the mixture $\left(2 \gamma\left[\mathrm{Sr}\left(\mathrm{PO}_{3}\right)_{2}\right]_{\infty}+\left[\mathrm{Mn}\left(\mathrm{PO}_{3}\right)_{2}\right]_{\infty}\right)$, (e) mixture $\left(2 \gamma\left[\mathrm{Sr}\left(\mathrm{PO}_{3}\right)_{2}\right]_{\infty}+\left[\mathrm{Mn}\left(\mathrm{PO}_{3}\right)_{2}\right]_{\infty}\right)$ and (f) mixture $\left(\left[\mathrm{Mn}\left(\mathrm{PO}_{3}\right)_{2}\right]+2 \beta\left[\mathrm{Sr}\left(\mathrm{PO}_{3}\right)_{2}\right]\right)$

2.6.3. Thermal dehydration of $\mathrm{MnSr}_{2}\left(\mathrm{P}_{3} \mathrm{O}_{9}\right)_{2} .4 \mathrm{H}_{2} \mathrm{O}$ by step manner of temperatures, at atmospheric pressure, by IR vibration spectrometry

The IR absorption spectra of $\mathrm{MnSr}_{2}\left(\mathrm{P}_{3} \mathrm{O}_{9}\right)_{2} .4 \mathrm{H}_{2} \mathrm{O}$ and its dehydration products at atmospheric pressure at $60^{\circ} \mathrm{C}$ are the same.

- At $100^{\circ} \mathrm{C}$, the absorption spectrum IR (Figure 4), remains virtually unchanged in the field of vibration cycles. The removal at this stage of a part of water (about two water molecules) of $\mathrm{MnSr}_{2}\left(\mathrm{P}_{3} \mathrm{O}_{9}\right)_{2} .4 \mathrm{H}_{2} \mathrm{O}$ does not affect the symmetry of the $\mathrm{P}_{3} \mathrm{O}_{9}{ }^{3-}$ rings. Indeed, the examination of the IR absorption spectrum of $\mathrm{MnSr}_{2}\left(\mathrm{P}_{3} \mathrm{O}_{9}\right)_{2} .2 \mathrm{H}_{2} \mathrm{O}$, shows that the product obtained is a cyclotriphosphate.

- At $150^{\circ} \mathrm{C}$, IR absorption spectrum of $\mathrm{MnSr}_{2}\left(\mathrm{P}_{3} \mathrm{O}_{9}\right)_{2} .4 \mathrm{H}_{2} \mathrm{O}$ (Figure 4), shows three new bands of low intensity at 938,881 and $844 \mathrm{~cm}^{-1}$ and 
which are not-existent in the IR spectrum of the initial phase. The band at $938 \mathrm{~cm}^{-1}$, whose intensity increases with temperature, indicates that it is a beginning of decondensation of the ring $\mathrm{P}_{3} \mathrm{O}_{9}{ }^{3-}$ cycle 7,8,9,10.

- At $300^{\circ} \mathrm{C}$, IR absorption spectrum of $\mathrm{MnSr}_{2}\left(\mathrm{P}_{3} \mathrm{O}_{9}\right)_{2} .4 \mathrm{H}_{2} \mathrm{O}$ (Figure 4), contains between 1400 and $600 \mathrm{~cm}^{-1}$, several frequencies which are all characteristic of polyphosphates with infinite chains, the vibration $v_{\mathrm{as}}$ POP, characteristic of polyphosphates with infinite chains, appears in the form of a very intense band at 926 and $890 \mathrm{~cm}^{-1}$.

- At $350^{\circ} \mathrm{C}$, IR absorption spectrum of $\mathrm{MnSr}_{2}\left(\mathrm{P}_{3} \mathrm{O}_{9}\right)_{2} .4 \mathrm{H}_{2} \mathrm{O}$ (Figure 4), contains between 1350 and $600 \mathrm{~cm}^{-1}$, several frequencies which are all characteristic of polyphosphates with infinite chains, the vibration $v_{\text {as }} P O P$, characteristic of polyphosphates with infinite chains, appears in the form of a very intense band at $944 \mathrm{~cm}^{-1}$.

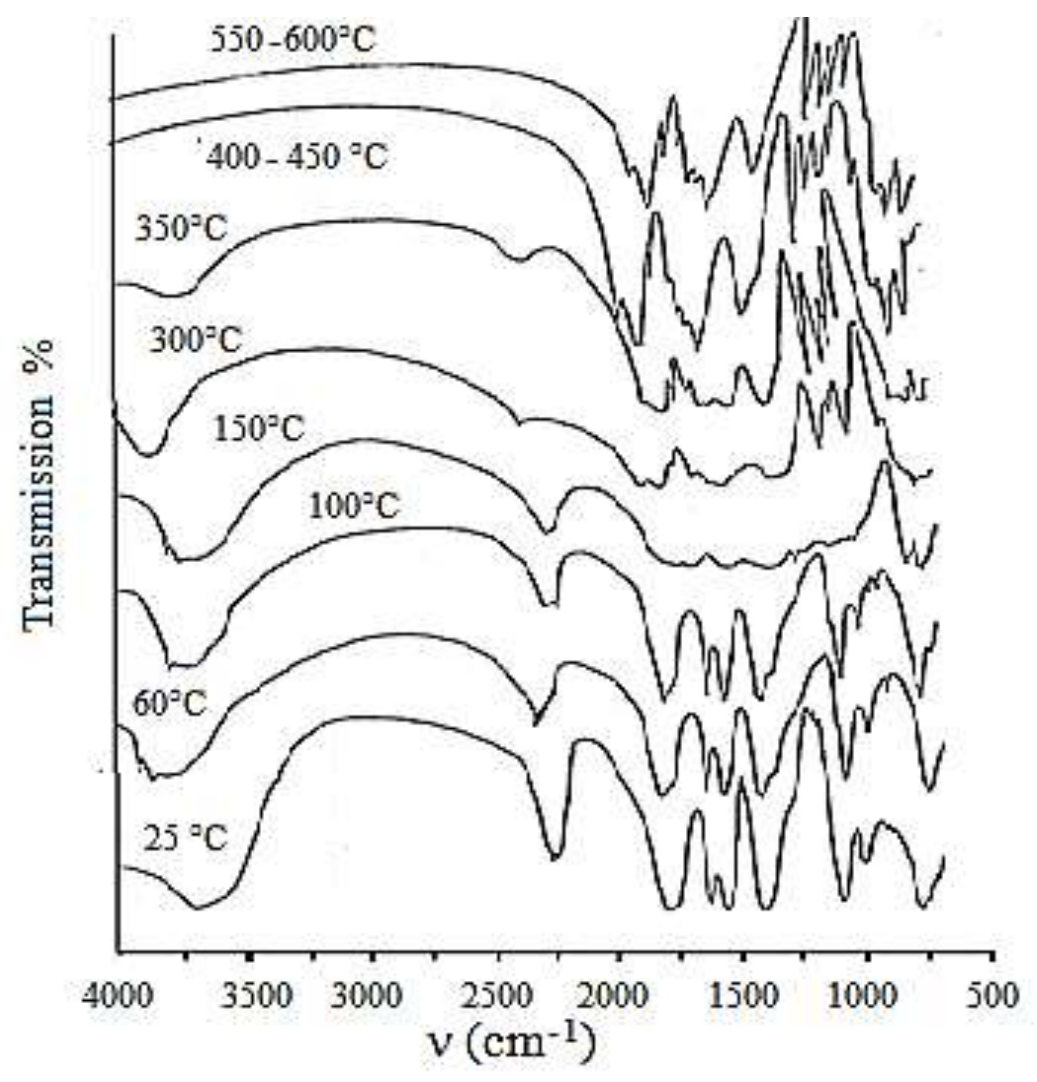

Figure 4. IR Absorption Spectra of $\mathrm{MnSr}_{2}\left(\mathrm{P}_{3} \mathrm{O}_{9}\right)_{2} .4 \mathrm{H}_{2} \mathrm{O}$ and its thermal dehydration products at atmospheric pressure

2.6.4. Thermal dehydration of $\mathrm{MnSr}_{2}\left(\mathrm{P}_{3} \mathrm{O}_{9}\right)_{2} .4 \mathrm{H}_{2} \mathrm{O}$ by the linear rise of temperature, under atmospheric pressure

\subsubsection{Thermogravimetric Analysis TGA}

Thermal dehydration by linear temperature rise under atmospheric pressure with a heating rate of $5^{\circ} \mathrm{C} / \mathrm{min}$ of the cyclotriphosphate, $\mathrm{MnSr}_{2}\left(\mathrm{P}_{3} \mathrm{O}_{9}\right)_{2} .4 \mathrm{H}_{2} \mathrm{O}$, gave the thermogravimetric curves shown in Figure 5. The thermogram obtained during the dehydration can be divided into three stages which are not very distinct because they are difficult to separate:

- The first step, between $70^{\circ} \mathrm{C}$ and $208^{\circ} \mathrm{C}$, during which the loss of mass is of $4.29 \%$ corresponds to the elimination of 1.85 moles of water. During this stage, the departure of water starts relatively quickly compared to the other two stages. The DTG thermogram indicates two minimums corresponding to two temperatures $91^{\circ} \mathrm{C}$ and $141^{\circ} \mathrm{C}$, for which the dehydration rates are maximum ${ }^{16}$;
- The second step between $208^{\circ} \mathrm{C}$ and $338^{\circ} \mathrm{C}$, during which there is a loss of mass of $3.34 \%$, which corresponds to the departure of 1.45 moles of water. During this step, the DTG thermogram shows a peak whose top temperature is $216^{\circ} \mathrm{C}$ and a shoulder at $235^{\circ} \mathrm{C}^{17}$.

- The third stage, between $338^{\circ} \mathrm{C}$ and $378^{\circ} \mathrm{C}$, for which the departure of the water takes place more slowly than the second stage. Between these temperatures, the mass loss is $1.63 \%$ and corresponds to 0.7 mole of water. The DTG thermogram shows an isolated and intense peak at $348^{\circ} \mathrm{C}$. At $387^{\circ} \mathrm{C}$, the overall mass loss recorded is $9.26 \%$ of the total mass of hydrate $\mathrm{MnSr}_{2}\left(\mathrm{P}_{3} \mathrm{O}_{9}\right)_{2}, 4 \mathrm{H}_{2} \mathrm{O}$ and therefore corresponds to the removal of four moles of water per unit formula. The thermal dehydration of $\mathrm{MnSr}_{2}\left(\mathrm{P}_{3} \mathrm{O}_{9}\right)_{2}, 4 \mathrm{H}_{2} \mathrm{O}$ is therefore total at this temperature. At temperatures above $380^{\circ} \mathrm{C}$, no loss of mass is observed. 


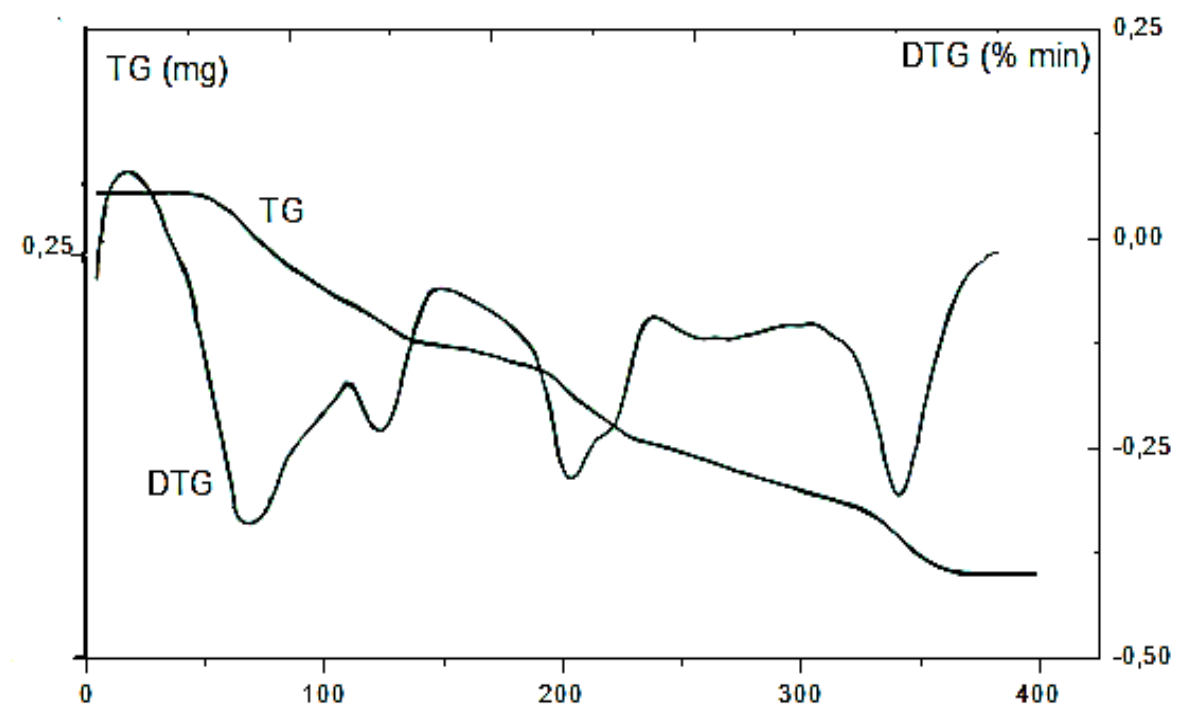

Figure 5.TGA (TG and DTG) curve of $\mathrm{MnSr}_{2}\left(\mathrm{P}_{3} \mathrm{O}_{9}\right)_{2}, 4 \mathrm{H}_{2} \mathrm{O}$ at rising temperature $\left(5^{\circ} \mathrm{C} \min ^{-1} / \mathrm{P}=1\right.$ atm $)$

\subsubsection{Differential Thermal Analysis (DTA)}

The differential thermal analysis curves (DTA) (Figure 6), carried out with a heating rate of $5^{\circ} \mathrm{C} / \mathrm{min}$, contains an exothermic peak and five endothermic peaks. The examination of the thermogram DTA, in the light of the DTG and DSC thermograms, carried out under the same conditions, shows that all the endothermic peaks are due to the departure of the water which is carried out in three stages. Indeed, at the endothermic peaks, whose peak temperatures at $93^{\circ} \mathrm{C}, 143^{\circ} \mathrm{C}, 217^{\circ} \mathrm{C}, 236^{\circ} \mathrm{C}$ and $351^{\circ} \mathrm{C}$ correspond to the DTG peaks whose peaks are observed at $91^{\circ} \mathrm{C}$, $141^{\circ} \mathrm{C}, 216^{\circ} \mathrm{C}, 235^{\circ} \mathrm{C}$ and $348^{\circ} \mathrm{C}$ respectively ${ }^{17}$.
The first two DTA peaks, at $93^{\circ} \mathrm{C}$ and $143^{\circ} \mathrm{C}$, correspond to the start of departure of the water molecules which occurs during the first stage and probably concerns the first type of water molecules. The two DTA peaks, located at $217^{\circ} \mathrm{C}$ and $236^{\circ} \mathrm{C}$, correspond to the departure of one mole of water which takes place during the second step and the last endothermic peak, whose peak is at $351^{\circ} \mathrm{C}$ corresponds to the departure of water that intervenes during the third and final stage. The exothermic peak whose summit is at $138^{\circ} \mathrm{C}$ is due to the crystallization of the intermediate hydrate, $\mathrm{MnSr}_{2}\left(\mathrm{P}_{3} \mathrm{O}_{9}\right)_{2} .2 \mathrm{H}_{2} \mathrm{O}$.

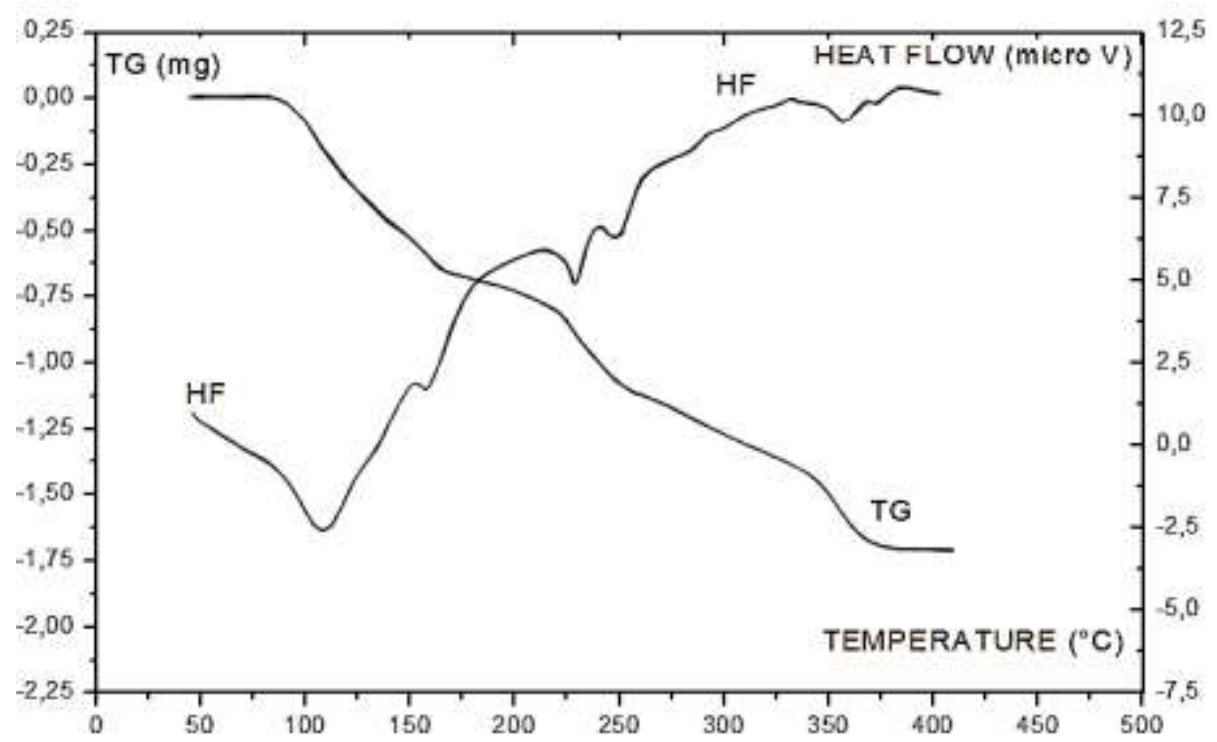

Figure 6. TGA and DTA curves of $\mathrm{MnSr}_{2}\left(\mathrm{P}_{3} \mathrm{O}_{9}\right)_{2} .4 \mathrm{H}_{2} \mathrm{O}$, at rising temperature $\left(5^{\circ} \mathrm{C} \mathrm{min}^{-1} / \mathrm{P}=1 \mathrm{~atm}\right)$ 
- The exothermic peak at $146^{\circ} \mathrm{C}$ could, therefore, be attributed to the crystallization of the dehydrated intermediate, $\mathrm{MnSr}_{2}\left(\mathrm{P}_{3} \mathrm{O}_{9}\right)_{2} .2 \mathrm{H}_{2} \mathrm{O}$.

- Based on this X-ray diffraction results, we were able to attribute the observed exothermic peak in the DSC curve at $169^{\circ} \mathrm{C}$ to the crystallization of the mixture $\left(\left[\mathrm{Mn}\left(\mathrm{PO}_{3}\right)_{2}\right]_{\infty}+2 \gamma\left[\mathrm{Sr}\left(\mathrm{PO}_{3}\right)_{2}\right]_{\infty}\right)$.

- The last exothermic peak observed in the DSC curve at $464^{\circ} \mathrm{C}$ corresponds to the crystallization of $\beta\left[\mathrm{Sr}\left(\mathrm{PO}_{3}\right)_{2}\right]_{\infty}$. This crystallization is accompanied by an enthalpy decrease of $8.75 \mathrm{Kcal} / \mathrm{mol}$ (Table 4 ).

\subsubsection{Differential scanning calorimetric (DSC)} The DSC curve of $\mathrm{MnSr}_{2}\left(\mathrm{P}_{3} \mathrm{O}_{9}\right)_{2}, 4 \mathrm{H}_{2} \mathrm{O}$ (Figure 7), with a heating rate of $5^{\circ} \mathrm{C} / \mathrm{min}$ has five peaks. of these five peaks, two are endothermic and are respectively at $118^{\circ} \mathrm{C}$ and $233^{\circ} \mathrm{C}$ and the other three are exothermic and are located at $146^{\circ} \mathrm{C}, 169^{\circ} \mathrm{C}$ and $464^{\circ} \mathrm{C}$.

- The peak observed at $118^{\circ} \mathrm{C}$ corresponds to the departure of two water molecules. The second endothermic peak at $233^{\circ} \mathrm{C}$ is attributable to the gaseous release of the remaining two water molecules of $\mathrm{MnSr}_{2}\left(\mathrm{P}_{3} \mathrm{O}_{9}\right)_{2}, 4 \mathrm{H}_{2} \mathrm{O}$

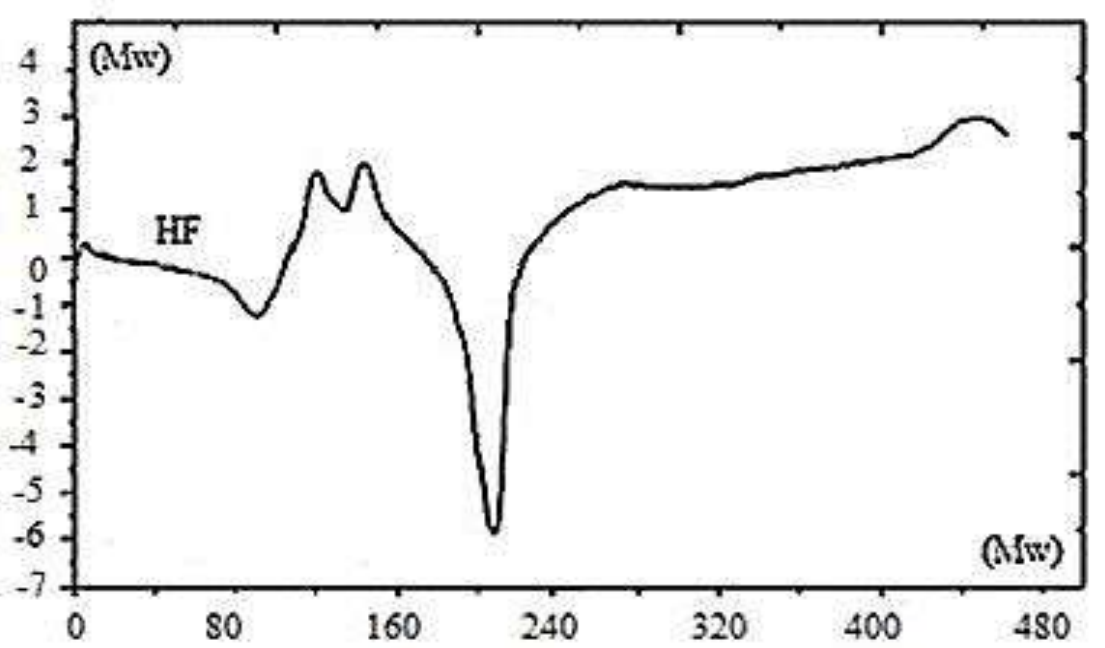

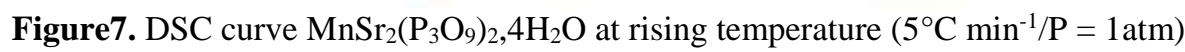

Table 4. Differential scanning calorimetry DSC $\left(\mathrm{v}=5^{\circ} \mathrm{C} / \mathrm{min}\right)$ of $\mathrm{MnSr}_{2}\left(\mathrm{P}_{3} \mathrm{O}_{9}\right)_{2} .4 \mathrm{H}_{2} \mathrm{O}$.

\begin{tabular}{|c|c|c|c|c|}
\hline & $\begin{array}{l}\mathrm{T}_{\mathrm{i}} \\
(\mathrm{k})\end{array}$ & $\begin{array}{l}\mathrm{T}_{\max } \\
(\mathrm{k})\end{array}$ & $\begin{array}{l}\mathrm{T}_{\mathrm{f}} \\
(\mathrm{K})\end{array}$ & $\begin{array}{l}\Delta \mathrm{H} \\
\left(\mathrm{kJ} / \mathrm{mol}^{-1}\right)\end{array}$ \\
\hline First peak & 374 & 391 & 410 & 19.65 \\
\hline Second peak & 410 & 419 & 432 & -11.84 \\
\hline Third peak & 434 & 442 & 457 & -10.51 \\
\hline Fourth peak & 486 & 506 & 560 & 120.01 \\
\hline Fifth peak & 714 & 737 & 757 & -8.75 \\
\hline
\end{tabular}

peak at $195^{\circ} \mathrm{C}$ when the speed heating is $10^{\circ} \mathrm{C} / \mathrm{min}$ (Figure 8). The heating rate is, therefore, an essential factor. In our case, there is a superposition of two phenomena at high speed, whereas if the heating rate is low, the two phenomena are separated ${ }^{17}$.
We have rescaled the differential scanning calorimetry (DSC) of $\mathrm{MnSr}_{2}\left(\mathrm{P}_{3} \mathrm{O}_{9}\right)_{2} .4 \mathrm{H}_{2} \mathrm{O}$, with a heating rate of $10^{\circ} \mathrm{C} / \mathrm{min}$ between $25^{\circ} \mathrm{C}$ and $400^{\circ} \mathrm{C}$ (Figure 8). The two exothermic peaks respectively at $146^{\circ} \mathrm{C}$ and $169^{\circ} \mathrm{C}$ with a temperature rise of $5^{\circ} \mathrm{C} / \mathrm{min}$ (Figure 7), are superimposed on a single exothermic 


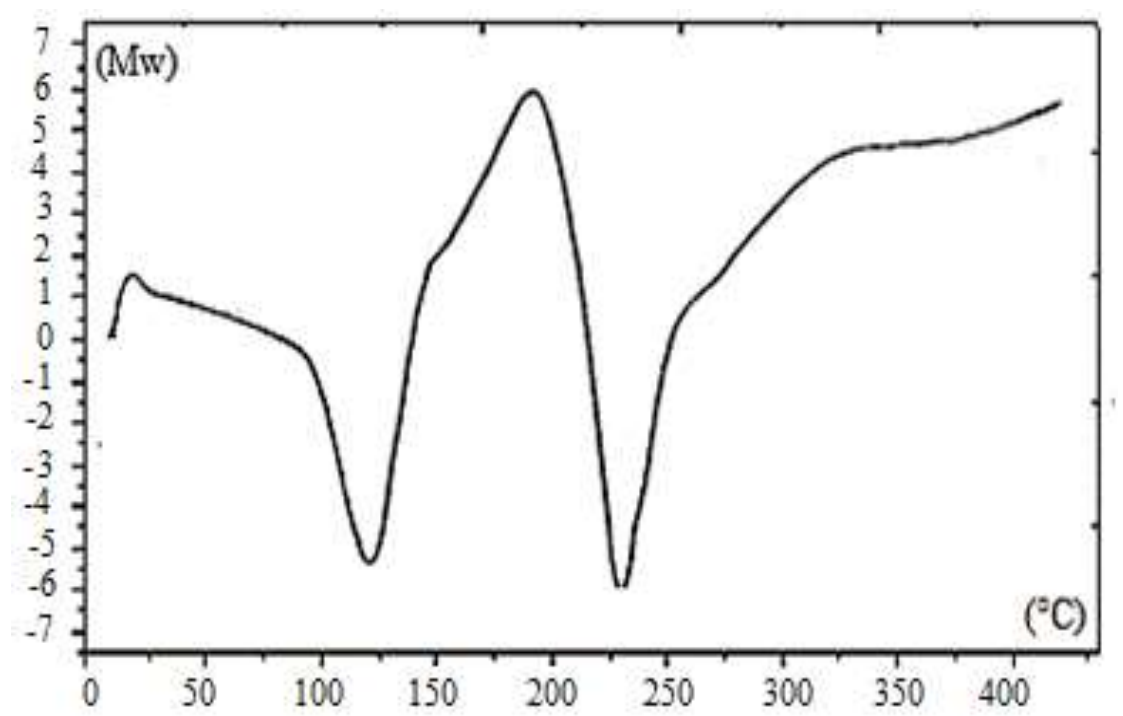

Figure 8. DSC curve of $\mathrm{MnSr}_{2}\left(\mathrm{P}_{3} \mathrm{O}_{9}\right)_{2}, 4 \mathrm{H}_{2} \mathrm{O}$ at rising temperature $\left(10^{\circ} \mathrm{C} \min ^{-1} / \mathrm{P}=1 \mathrm{~atm}\right)$

\section{Conclusion}

The present work concerns the preparation, crystallographic characterization and vibrational study of a new cyclotriphosphate tetrahydrate of manganese and distrontium, $\mathrm{MnSr}_{2}\left(\mathrm{P}_{3} \mathrm{O}_{9}\right)_{2} \cdot 4 \mathrm{H}_{2} \mathrm{O}$. The thermal evolution of $\mathrm{MnSr}_{2}\left(\mathrm{P}_{3} \mathrm{O}_{9}\right)_{2} .4 \mathrm{H}_{2} \mathrm{O}$ has been followed by thermal analyses TGA and DTA, X-ray diffraction and infrared spectrometry. The calcination of $\mathrm{MnSr}_{2}\left(\mathrm{P}_{3} \mathrm{O}_{9}\right)_{2} .4 \mathrm{H}_{2} \mathrm{O}$ at $400^{\circ} \mathrm{C}$ results in a mixture of infinite chain polyphosphates, $\left(\left[\mathrm{Mn}\left(\mathrm{PO}_{3}\right)_{2}\right]_{\infty}+2 \gamma\left[\mathrm{Sr}\left(\mathrm{PO}_{3}\right)_{2}\right]_{\infty}\right)$. X-ray diffraction has shown that above $450^{\circ} \mathrm{C}$ there is an allotropic transformation of $\gamma\left[\mathrm{Sr}\left(\mathrm{PO}_{3}\right)_{2}\right]_{\infty}$ to $\beta\left[\mathrm{Sr}\left(\mathrm{PO}_{3}\right)_{2}\right.$. The final product resulting from the thermal dehydration of $\mathrm{MnSr}_{2}\left(\mathrm{P}_{3} \mathrm{O}_{9}\right)_{2} .4 \mathrm{H}_{2} \mathrm{O}$ at $550^{\circ} \mathrm{C}$ is the polyphosphate mixture $\left(\left[\mathrm{Mn}\left(\mathrm{PO}_{3}\right)_{2}\right]_{\infty}+2 \beta\right.$ $\left.\left[\mathrm{Sr}\left(\mathrm{PO}_{3}\right)_{2}\right]_{\infty}\right)$.

\section{Acknowledgements}

The authors thank the Laboratory of ChemistryPhysics of Materials, Faculty of Sciences Ben M'Sik B. P. 7955, Hassan II University of Casablanca, Morocco for infrared spectroscopy measurements.

\section{Experimental}

\subsection{Chemical analyses}

Chemical analyses were performed on a spectrophotometer of atomic absorption-type VARIAN AA-475.

\subsection{Infrared spectrometry}

Spectra were recorded in the range $4000-400 \mathrm{~cm}^{-1}$ with a Perkin-Elmer IR $983 \mathrm{G}$ spectrophotometer, using samples dispersed in spectroscopically pure KBrpellets.

\subsection{Thermal behavior}

Thermal analyses TGA-DTA coupled were performed using the multimodule 92 Setaram Analyzer operating from room temperature up to $1400^{\circ} \mathrm{C}$, in a platinum crucible, at various heating rates from 1 to $15^{\circ} \mathrm{C} / \mathrm{min}$. Differential scanning calorimetry (DSC) was carried out with a Setaram DSC 92 apparatus.

\subsection{X-ray diffraction}

Powder diffraction patterns for the two title compound were collected with a SIEMENS D 5000 diffractometer using $\mathrm{Cu} \mathrm{K} \alpha 1$ radiation $(\lambda=1.5406 \AA)$. The experimental $2 \theta$ range was from 5 to $70^{\circ}(2 \theta)$ with a step size of $0.01^{\circ}$ and a counting time of the $30 \mathrm{~s}$ per step. The program of graphic tool for powder diffraction named WinPLOTR was used to determine the observed diffraction peak positions for $\mathrm{MnSr}_{2}\left(\mathrm{P}_{3} \mathrm{O}_{9}\right)_{2} .4 \mathrm{H}_{2} \mathrm{O}$. The unit-cell parameters of $\mathrm{MnSr}_{2}\left(\mathrm{P}_{3} \mathrm{O}_{9}\right)_{2} .4 \mathrm{H}_{2} \mathrm{O}$ were calculated using the computer program Dicvol ${ }^{6}$.

\section{References}

1- F. Álvaro, R.A. Johnstone, High surface area Pd, $\mathrm{Pt}$ and $\mathrm{Ni}$ ion-exchanged $\mathrm{Zr}$, Ti and Sn (IV) phosphates and their application to selective heterogeneous catalytic hydrogenation of alkenes, Journal of Molecular Catalysis A: Chemical, 2008,280 (1-2),131-41. DOI:10.1016/j.molcata.2007.10.031

2- A. Durif, M.T. Averbuch-Pouchot, J.C. Guitel, Crystalline structure of barium-zinc trimetaphosphatedecahydrate: $\mathrm{Ba}_{2} \mathrm{Zn}\left(\mathrm{P}_{3} \mathrm{O}_{9}\right)$ 2. $10 \mathrm{H}_{2} \mathrm{O}$, Acta Crystallographica Section B, 1975, 31 (11), 2680-2682. DOI: $10.1107 / \mathrm{s} 056774087500845 \mathrm{x}$.

3- M. Tridane, S. Belaaouad, K. Sbai, Chemical preparations and crystal data for eight new condensed phosphates, Solid-state sciences, 2000, 7, 701-704. DOI:10.1016/S12932558(00)01081-5.

4- K. Sbai, M. Tridane, A. Abouimrane, S. Belaaouad, A. Cherqaoui, Chemical preparation and crystal data for two new cyclotriphosphates 
$\mathrm{M}^{\mathrm{II}} \mathrm{K}_{4}\left(\mathrm{P}_{3} \mathrm{O}_{9}\right)_{2}\left(\mathrm{M}^{\mathrm{II}}=\mathrm{Co}^{2+}\right.$ and $\left.\mathrm{Mn}^{2+}\right)$, Powder Diffraction, 2003,18(3),224-6. DOI:10.1007/s100190000057

5- S. Belaaouad, K. Sbai, Chemical preparation and crystal data for two new condensed phosphates, Powder Diffraction, 2002,17(1),23-4. DOI:10.1154/1.1420710

6- A. Boultif and D. Louër, Powder pattern indexing with the dichotomy method, Journal of Applied Crystallography, 2004, 37, 724-731. DOI:10.1107/S0021889804014876.

7- S. Zerraf, M. Belhabra, A. Kheireddine, R. Lamsatfi, M.Tridane, H. Moutaabbid, B. Baptiste, M. Moutaabbid and S.Belaaouad, Reinvestigation of the crystal structure of barium cesium cyclotriphosphatedihydrate and vibrational study, Phosphorus, Sulfur, and Silicon and the Related Elements, 2017, 192, 12861293..DOI:10.1080/10426507.2017.1333507.

8- S. Zerraf, M. Tridane, S. Belaaouad, Data of infrared vibration spectroscopy of cyclotriphosphates, Data in Brief, 2019, 25,104075. DOI: 10.1016/j.dib.2019.104075.

9- M. Belhabra, S. Zerraf, A. Kheireddine A. Altomare, M. Tridane, A. Ouasri, M. Radid and S. Belaaouad, Structural and vibrational study of diphenylhydrazinedihydrogenophosphate single crystal $\left(\mathrm{C}_{6} \mathrm{H}_{9} \mathrm{~N}_{2}\right)_{2} \mathrm{H}_{2} \mathrm{P}_{2} \mathrm{O}_{7}$ (DPHDP), Chemical Data Collections, 2018,13, 73-83. DOI:10.1016/j.cdc.2018.01.002.

10- A. Atibi, K. El Kababi, S. Zerraf, M. Tridane, S. Belaaouad, Chemical preparation crystal structure and vibrational study of a new dihydrogenotriphosphatetrihydrate of 4aminobenzoic acid fertilizer type NP, Journal of Coordination Chemistry, 2018, 71, 3510-3520. DOI: $10.1080 / 00958972.2018 .1528579$.

11- M. Belhabra, I. Fahim, A. Atibi, K. El Kababi, A. Ouasri, S. Zerraf, M. Tridane, M. Radid, S. Belaaouad, Vibrational study and thermal behavior of dihydrogenotriphosphatetrihydrate of 4-aminobenzoic acid and its anhydrous new form fertilizer type NP, Mediterranean Journal of Chemistry, 2019, 270-82.

DOI:10.13171/mjc841905308mb.

12- M. Graia, A. Driss, T. Jouini, Polyphosphates de strontium $\mathrm{Sr}\left(\mathrm{PO}_{3}\right)_{2}$ formes $\beta$ et $\gamma$. Acta

Crystallographica Section C: Communications en structure crystalline, 1999, 55, 1395-8. DOI: $10.1107 /$ S0108270199003637

13- HA. Höppe, The synthesis, crystal structure and vibrational spectra of $\alpha-\mathrm{Sr}\left(\mathrm{PO}_{3}\right)_{2}$ containing an unusual catena-polyphosphate helix. Solid-state sciences, 2005, 7(10), 1209-15. DOI:10.1016/j.solidstatesciences.2005.06.014.

14- M.P. Gashti, M. Stir, J. Hullinger, Growth of strontium hydrogen phosphate/gelatin composites: a biomimetic approach, New journal of chemistry, 2016, 40(6), 5495-500. DOI: 10.1039/c5nj03575a.

15- M. Weil, M. Uchberger, J. Schmedtauf der Guenne, J. Weber, Synthesis, Crystal Structure, and Characterization (Vibrational and Solid-State 31P MAS NMR Spectroscopy) of the HighTemperature Modification of Calcium catenaPolyphosphate (V), Chemistry of Materials, 2007,19(21), 5067-73. DOI:10.1021/cm071239i.

16- S. Belaaouad, M. Tridane, H. Chennak, R. Tamani, A. Kenz, M. Moutaabbid, Chemical preparation, thermal behavior, kinetic and infrared studies and quantum chemical calculations of $\mathrm{Ca}_{3}\left(\mathrm{P}_{3} \mathrm{O}_{9}\right)_{2} \cdot 10 \mathrm{H}_{2} \mathrm{O}$, Phosphorus Research Bulletin, 2007,21,60-70. DOI: $10.3363 /$ prb.21.60.

17-S. Belaaouad, Y. Lahrir, S.Sarhane, M. Tridane, Chemical preparation, thermal behavior, kinetic and infrared studies and quantum chemical calculations of $\mathrm{Ba}_{3}\left(\mathrm{P}_{3} \mathrm{O}_{9}\right)_{2} \cdot 6 \mathrm{H}_{2} \mathrm{O}$, Phosphorus Research Bulletin, 2009, 23, 67-75. DOI:10.3363/prb.23.67. 